\title{
Chapter 8. Origin Structures and Precedence in the Social Orders of Tana 'Ai and Sikka
}

\section{E. D. Lewis}

Both the people (ata) of Tana 'Ai and of Sikka, who inhabit the Regency of Sikka in east central Flores, refer to the past and, specifically, to myths of origin to explain the "sources" of the various groups which constitute their societies. The mapping of contemporary social organization onto events of the past and the invocation of mythic histories to explain the contemporary relations of social groups is significant in attempting to explain the apparent rank ordering of the social groups. Thus, in east central Flores, the legitimation of contemporary forms of social order is founded in contingent sequences of past events and it is with these representations of events, in history, that an analysis of hierarchy in Tana 'Ai and Sikka must begin. The result of such analyses is the specification of what Fox (1988:10-14) has termed "origin structures".

Origin structures are the representations of history by which contemporary social organization is legitimated and explained. Both the Ata Tana 'Ai and the Ata Sikka possess myths in which these origin structures are encoded. In both representations, a principle by which society is ordered is precedence, the sequence in time in which the constituent groups of society were founded or in which they became members of society. However, because origin structures are dependent upon contingent events, they differ from one society to another. What is consistent in both Tana 'Ai and Sikka is the centrality of precedence, the interplay of dual divisions of authority, and the role of alliance and exchange in the representation of society. In this paper, I will be concerned with the different ways in which these features of origin structures have operated to produce different social organizations in Tana 'Ai and Sikka, two societies which are closely related culturally.

\section{Clans, Houses and History: The Origin Structure of Tana Wai Brama}

The mythic histories which recount the foundation of the Tana 'Ai domain of Tana Wai Brama are essentially the story of one clan, Sukun Ipir Wai Brama, whose ancestors, Hading Dai Dor and Uher La'i Atan, were the first people to find and settle the land of the domain. The stories of the subsequent arrivals of the ancestors of clans Tapo, Mau, Magé and Liwu, the lesser clans of Tana Wai Brama, are cast in relation to the temporal priority and social and ceremonial 
precedence of Sukun Ipir. The ngeng ngerang, "history", of each subordinate clan establishes the legitimacy of the clan by tracing its obligations and prerogatives in the ceremonial system of the domain, its rights to land and its hadat ("customs", "rituals") to prestations by the ancestors of Ipir. The relations of the five clans to one another are thus founded, not on the reckoning of common origin or descent from a common ancestral line, but are represented as deriving from ceremonial alliances formed among people who were, originally, quite alien to one another. In this respect, it is proper to conceive of the domain of Wai Brama as consisting of peoples of five different nations joined in a confederation held together by a single ceremonial regime, what the people of Tana Wai Brama refer to as hadat. This regime is essentially that of clan Ipir, the founding, and hence pu'an ("source", "trunk") clan. The precedence of the clans of the domain is, as a consequence, strictly that whereby Ipir holds ultimate rights to the land, rights which over time were delegated variously to clans Tapo, Mau, Magé and Liwu. In all matters pertaining to hadat, Ipir is source and arbiter and, in ritual practice, is acknowledged as holding oda, "precedence", over all others, even those to whom the right to perform a rite may have been delegated.

Each clan consists of a number of "houses", the relations among which, in parallel to the order of clans in the domain, are ordered in terms of their precedence. The oda of houses within a clan is determined by the sequence of events in time by which the various houses were founded. Older houses are temporally closer to the source and thus take social and ceremonial precedence over more recently founded houses.

\section{Protogenitrix Lines and the Precedence of Houses Within Tana 'Ai Clans}

Every brother-sister pair in Tana Wai Brama is potentially the source of a new house. The socially reproductive potentialities of cross-sex siblingship are realized only when one of the pair, or both, marry someone of a different clan. A consequence of interclan marriage is the alienation of the brother's "blood" from his own maternal descent group, since "blood" and descent group affiliation are transmitted from mothers to daughters only. When a man who was father to children in a clan other than his own dies, one of his daughters, who is a member of her mother's clan, is returned to the father's clan, wherein she becomes the founder of a new house. Intraclan marriages entail no such exchanges since the father's blood remains within his clan, if not within his natal house. Thus each house in Tana Wai Brama traces its origin to a genitor (a father) of its own clan and a genitrix (a mother) of another clan. However, the genitrix, or ina puda, "ancestral mother" or "founding, original mother", is the ancestor of greater importance whose name identifies the house. Thus all of her descendants through women are her pun and it might be said, for example: "Ami lepo é'i Dala pun", "We of this house are Dala's people (Dala's descendants)". While people who 
are descended from a named ina puda constitute a group, these groups themselves recognize common origins in a prior protogenitrix line which locates its ancestry and source in the line of the ina ama pu'an, the founding ancestors of the clan. For reasons I have outlined elsewhere (Lewis 1988:231-232, 309-310), the source houses and older protogenitrix lines of a clan tend to die out, but the proliferation in time of new houses allied to protogenitrix lines insures the continuation of the clan.

The people of each house also recognize, in addition to a genitrix, a protogenitrix, either by name or, more commonly, by reference to the living descendants of the protogenitrix. Protogenitrix lines are those which were generated directly from the origin line of the clan, that is, the direct descendants through women of the clan's founding ancestors. It is through the links of genitor/genitrix and genitrix/protogenitrix that an Ata Tana 'Ai calculates a house's origin and its relation to the founding ancestors. A clan in Tana Wai Brama is thus a good example of what Fox has called an "origin group", that is, a group of people who:

claim to share and to celebrate in some form of common derivation. This derivation is socially constructed and may be variously based on the acknowledgment of a common ancestor, a common cult, a common name or set of names, a common place of derivation, and/or a share in a common collection of sacred artefacts (Fox this volume:132).

This point is important for the analysis of the society of Tana Wai Brama because it indicates that at the heart of the domain's constitution is the idea that the domain's clans are fundamentally social entities of independent and diverse origins, even though in contemporary times they are closely bound together by both ritual and affinal relations. It is nevertheless the case, however, that the principles which govern the generation and organization of houses within the domain's clans are the same.

\section{The Generation of Houses Within Tana 'Ai Clans}

New houses are generated within a clan by the exchange of a man's daughter as ama 'lo'en, "father's forelock", for gongs and elephant tusks, the exchange occurring between two houses of different clans. While the dynamics and mechanism of these exchanges and their consequences can be demonstrated in genealogical terms (see Lewis 1988), the people of Tana Wai Brama do not themselves conceive of them primarily in this way. Rather, the idiom and metaphors they employ are those of the distinction between the trunk and leafy tips of a tree and the generation of offshoots from the nodes of a bamboo's culm. The mode of representation is thus, in terms of the Ata Tana Wai Brama themselves, a cladistic one in which a contemporary set of relationships among houses is the result of historical bifurcations from an original line of women. 
While the genealogical relationships between house founders and their descendants may be remembered, it is not necessary to know them in detail in order to calculate the status of a house or individual in a clan. In effect, the contemporary rank ordering of houses preserves and collapses into the present relations of temporal precedence which result from dynamic processes of generation and reproduction. These relationships are represented as much, if not more, in established patterns of ceremonial and ritual obligation than in genealogy.

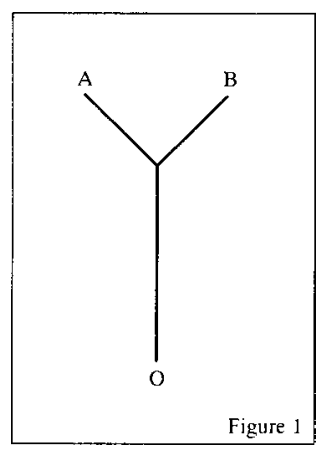

The first principle of the generation of a new house is that the protogenitrix line abides and survives the generation of the new house to coexist with it. This is a crucial point in the logic of precedence by which clans are organized. The bifurcation of a trunk can take place in two ways (Figure 1).

In this case, $A$ and $B$ both have their origins in $O$ (origin), but neither is $O$. As a consequence, $O$, having given rise to two branches, that is, to two new lines simultaneously, disappears. The Ata Tana 'Ai liken this pattern of bifurcation to that of a tree's trunk at its first branching.

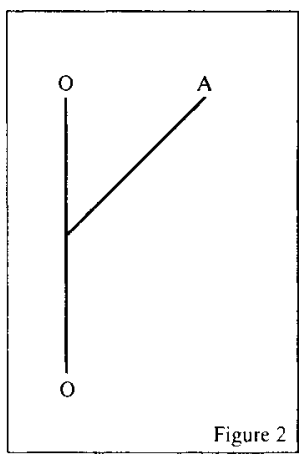

The second way a trunk can bifurcate is one which preserves the trunk while still generating new growth (Figure 2).

As the Ata Tana 'Ai pointed out to me, a tree's trunk can give rise to only two branches, but a bamboo's culm can give rise to many branches, one or more at each of its matan, "nodes". Indeed, in order for this to happen the trunk, or origin, must be preserved throughout the chain of branchings. Thus, sequential bifurcations from the trunk can give rise to the pattern shown in Figure 3.

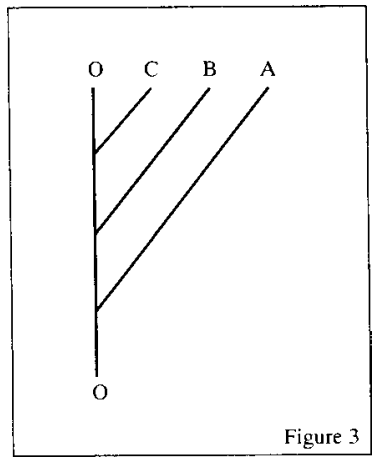

In this representation, a single, surviving trunk has given rise to many branches, one after another in sequence. This is the pattern of generation of houses within a clan and it is perhaps for this reason that the morphology of the bamboo is the most frequent source of metaphors for processes of social generation and reproduction in ritual language (cf. Lewis 1988:73-76).

Both patterns can, logically, provide the basis for the generation and differentiation of social groups from a single source. In the first case, however, two features of generation which 
may be exploited ideologically and in the ordering of the relations of social groups are lost. First is the temporality of the bifurcation. Both offspring groups are generated at the same time and, as a consequence, priority (or sequence) of generation cannot be invoked as a basis for subsequent differentiation of the groups without the imposition of another, externally derived principle. Second, neither group can be related in any material way to the origin line after the bifurcation because the origin line has ceased to exist of itself. Thus, the second pattern is perhaps better suited for the calculation of precedence, upon which the relationships of houses in Tana Wai Brama are articulated; first, because the origin group is always present and can more easily serve as the point of reference in the system and, second, because the generation of new groups occurs as a sequence of discrete events, each of which gives rise to one new group rather than to two. Thus, the new group can be juxtaposed to and differentiated from the original line without the invocation of additional principles, but merely by the application of a single value which accords superiority to the elder and relative inferiority to the younger. This single rule, applied sequentially as new lines are generated from a line of origin, is sufficient to order a limitless number of new lines in terms of precedence.

Not all houses in a clan of Tana Wai Brama arise directly from the line of ancestral founders. Houses, once generated, can themselves generate new houses, thus giving rise to the pattern implicit in Figure 4.

Two major conclusions may be drawn from this rather formalistic consideration of Tana 'Ai clanship.

First, if the order of society is considered atemporally at a particular moment in its history, then we might be led to conclude that Tana Wai Brama is a good example of a society consisting of rank-ordered groups - that is, that it consists of hierarchically ordered social groups. This conclusion would, of course, be in error. As time passes, old groups die out and new groups are created. As these events unfold, the statuses of individual persons change, sometimes radically, as when a high ranking group becomes pu'an, "source", within its clan. 


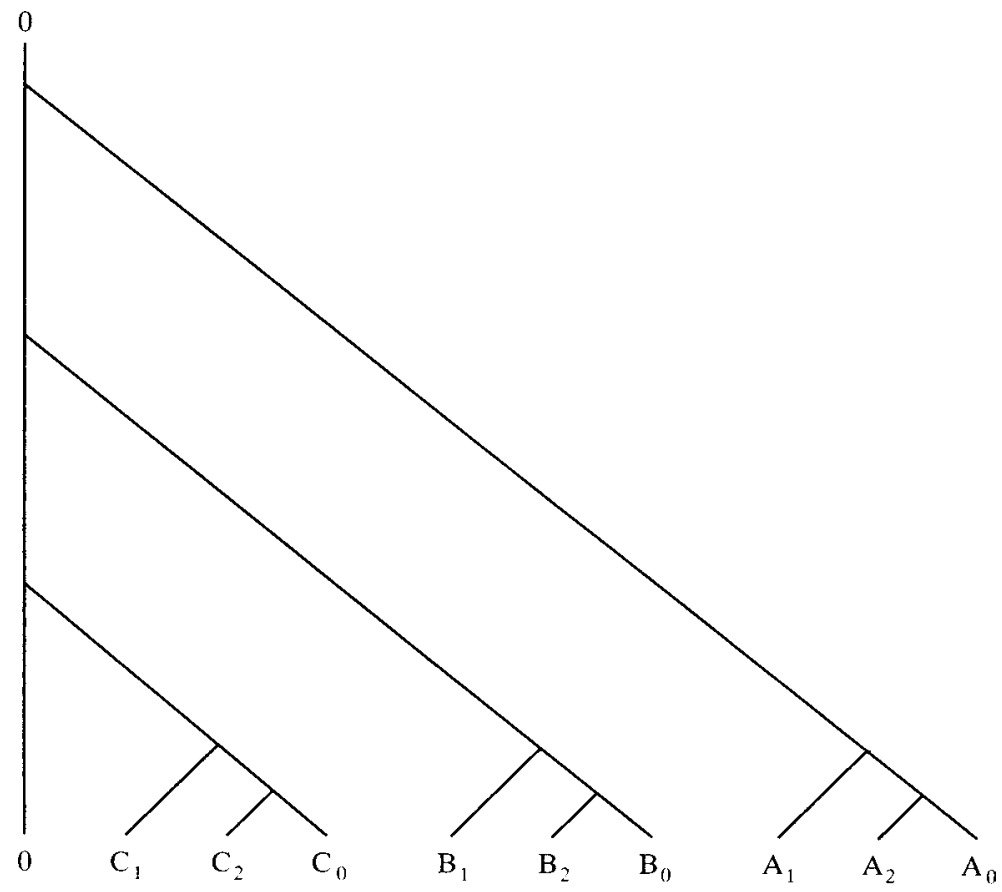

Figure 4

Second, in such a dynamic system, there is considerable scope for the negotiation of relationships in particular circumstances. For example, a particular exchange might occur which appears to violate rules governing the relations between groups of different status, but which does not threaten the whole system. Thus, this is a social order which is not only dynamic, but also extremely flexible and resilient to individual action contrary to accepted norms.

To this point I have dealt with what might be thought of as the fundamental order of the constituent groups of society, an order sanctioned in the mythic histories of the domain and articulated in its most important exchanges - i.e., in marriage. My argument has been that precedence, rather than hierarchy, is the fundamental operator which gives Tana 'Ai society its particular form.

There is, however, another aspect of hierarchy which must be considered in relation to the Tana 'Ai case, and that has to do with authority and power in Tana 'Ai society.

\section{Precedence and the Delegation of Authority in Tana Wai Brama}

In Tana Wai Brama, all rituals are celebrations of origins and the authority to conduct ritual is vested ultimately in the tana pu'an, the "Source of the Domain", who is always a man of clan Ipir and who, as a living descendant of the founding 
ancestors of the domain, is responsible for the maintenance of hadat, especially in matters pertaining to the relations of people to the land. However, the tana pu'an rarely performs ritual himself. Rather, he delegates to others the performance of particular rituals, just as the ancestors of clan Ipir delegated land and rights in the ceremonial system to the lesser clans of the domain. Thus, each clan of Tana Wai Brama includes a number of ritual specialists, each of whom is a chanter who knows the ngeng ngerang, the mythic histories, of his clan and who is skilled in the conduct of ritual. As these leaders derive their authority in ritual from the tana pu'an, so too do they further delegate the actual performance of ritual to other men who, in turn, may delegate further, even to young boys. Such delegations of the performance of ritual are represented in terms of oda, "precedence", such that whoever might actually sacrifice an animal in a ritual will say that he has been told to do so by someone else closer to the "source" of authority in the community.

Thus, with respect to the pragmatics of ritual performance in Tana Wai Brama, the Source of the Domain, the ritual leader of the community, delegates his authority to a hierarchy of ritual specialists who are thereby empowered to act, according to hadat on behalf of the Source. While the people of Tana Wai Brama locate the origin of the Source's authority in the mythic origins of the domain, they also say that his authority to act in particular situations derives from his sisters. A good example of how this works out in practice is the sacrifice of animals in ritual. An animal is usually killed by a person who lacks authority in the ritual. This actor is empowered through delegation to kill the animal by a ritual specialist who, in turn, has received his power by delegation from a higher ranking ritual specialist, and so on. The concatenation of delegation originates with the Source of the Domain. What this means is that the person one sees doing something is the least likely person to claim the primary authority to be doing that thing.

In daily life, in the cycle of annual rituals and in the larger ceremonial cycles which are completed over a number of years, the delegation of ritual performance recapitulates and is modelled on the precedence ordering of social groups in the community, which itself derives from the precedence, the origin structure, of society as a whole. Similar conceptions of order and of the nature of authority and power are found in Sikka, which, despite possessing a culture closely related to that of the Ata Tana 'Ai, has had quite a different history.

\section{Precedence, Delegation and the Origin Structure of Sikka}

The people of Sikka Natar, the village of Sikka, occupy an inhospitable sliver of sandy reef which faces the tempestuous waters of the Savu Sea and backs onto the degraded hills of the southern escarpment of the island of Flores. Despite the poverty of the site of the village or, as some Ata Sikka (People of Sikka) argue, because of it, the people of the village have traditionally made their living 
neither by agriculture nor by fishing, as have other villages to the west and east; rather, the village was, until 1954, the seat of Kerajaan Sikka, the Rajadom of Sikka, a petty state, a confederation of villages and domains, which at one time encompassed much of east central Flores and, the Sikkanese claim, regions beyond. The people of this unprepossessing little village secured their livelihood, first, as rulers and, later, as educators, government officials, traders and proprietors of land in other parts of the island. Today, the Ata Sikka still live to some extent off economic, political and social capital amassed during more than three centuries of rule and their identity as former rulers informs their contemporary relations with other peoples of Flores. Even though the Rajadom of Sikka was wholly dissolved by the end of the 1950s, other peoples of Flores still regard Sikka Natar as one of the important centres of high culture on the island of Flores. For the Ata Sikka themselves, the unique past of their village as the centre of a negeri, a "nation", is the most potent of many features of their history and culture which define them as distinctive from - and, indeed, superior to - their neighbours. ${ }^{1}$

As in Tana Wai Brama, the history of Sikka is the history of the coming together of different peoples to create a single society which nevertheless remains a confederation of groups, each of which has its own unique history. In Sikka, the histories of these origin groups are recounted both in oral narratives and in a body of written works. One of the written histories is a history of the Rajadom of Sikka written by Mo'ang D.D.P. Kondi, a minister in the government of the last Raja of Sikka, Raja Don Thomas Ximenes da Silva, some time after the Second World War and in the closing years of the Rajadom. ${ }^{2}$

Just as the ngeng ngerang of Tana Wai Brama is primarily the history of the founding clan of the domain, so too is Kondi's account of the history of Sikka that of the founders of Sikka, the descendants of a protogenitor line whose members brought into a confederation people of diverse origins. The history thus reveals, in textual form, the origin structure of the Sikkanese royal house and provides a detailed foundation for the legitimacy of the power and authority of the Rajas of Sikka over their domain. Furthermore, the historical narrative provides information sufficient to legitimate the social and political positions of all those persons and groups other than the royal lineage who claim authority in the contemporary community. Thus, there are many detailed accounts of the conclusion of alliances between the Rajas of Sikka and the heads and tana pu'ang ("sources of the earth") of various villages and minor domains on Flores (see Figure 5). 


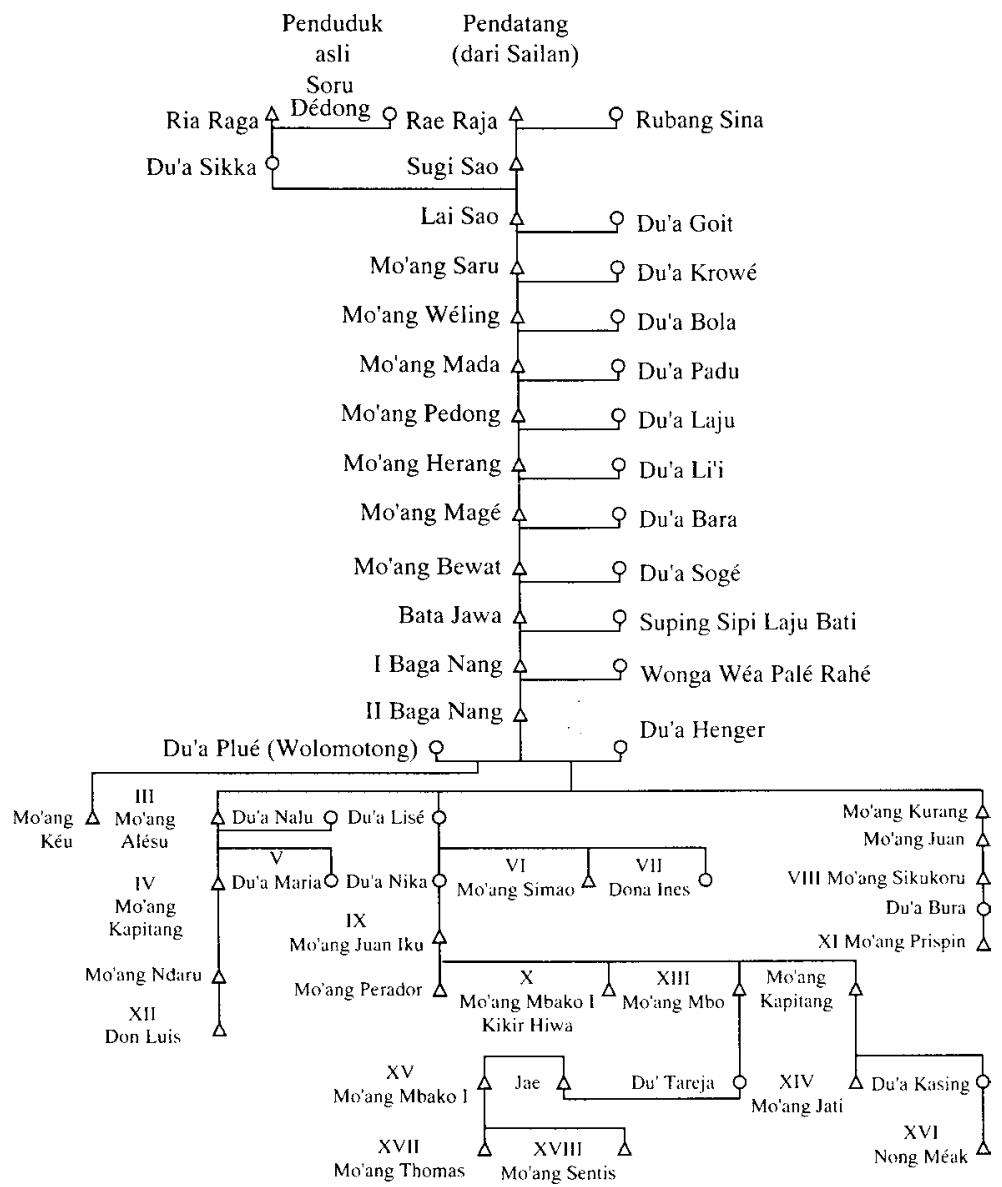

Figure 5. A version of the genealogy of the Ratu of Sikka. [Source: Mo'ang Mandalangi Pareira, Sikka Genealogy Book, pp.112ff.]

Among the Ata Sikka, claims to title, power, authority and precedence are not made alone by reference to the events by which the ancestors of the rajas established the community, but also by reference to a dynastic genealogy of the rajas. This dynastic genealogy establishes at once the origins and succession of power in the rajadom and, insofar as a person or group can demonstrate relatedness to the royal lineage, the legitimacy of power and precedence which devolved from the royal house of Sikka to the mo'ang pulu, "the ten lords" (the noble houses of Sikka which are closely allied politically and historically to the rajas' house) and, through them, to all the residents of the domain.

In their oral traditions, the Ata Sikka trace the origin of Sikka Natar to the man Ria Raga and his wife, Soru Dédong, who were "penduduk asli" (Malay: "native inhabitants") of Sikka. Their daughter, Du'a Sikka, married Sugi Sao, the son of the man Rae Raja and his wife, Rubang Sina, who were "pendatang 
dari Sailan" (Malay: "immigrants from Ceylon"). Du'a Sikka gave birth to Lai Sao, whose male descendants are traced through eleven generations of men to Don Alésu, the first ratu of the Rajadom of Sikka. The names of the ancestors who appear in the genealogy of the Sikkanese royal house are significant. Among the wives of the descendants of Lai Sao are Du'a Krowé, Du'a Bola and Du'a Sogé. Krowé is the region of the central hills of Sikka, from which the rulers of Sikka originated, and Bola is a village on the south coast of Flores to the east of Sikka Natar. Both Krowé and Bola are areas later incorporated into the Rajadom of Sikka. Sogé is the Sikkanese word for Ende, from where a large number of immigrants to Sikka fled after a war between Endenese Catholics and Muslims, which the Catholics lost.

Du'a Sikka's husband, a foreigner, was named "Raja", which means "ruler". Du'a Sikka herself bears the name of the future Rajadom and it is significant that she, who was of autochthonous origin, was female. She was, by implication, tana pu'ang, the "source of the earth". In terms of precedence, Du'a Sikka was thus prior to her husband, just as the Sources of the Earth of Sikka were of greater precedence than the rajas who, while they were rulers, were descendants of a male outsider. As elsewhere in eastern Indonesia, these representations take on special significance because Sikka had a diarchic division of authority between the lord or source of the earth who held ritual authority over the land and who was classified as feminine and the ratu, the secular ruler who was classified as masculine in terms of an encompassing system of dual symbolic classification. The genealogy of the rajas of Sikka is thus traced through an unbroken line of males to a male immigrant who married an indigenous woman. In ritual language it is said, "ina Sikka ama jawa", "the mother (from) Sikka, the father from far away" and "ina ratu ama raja", "the mother (was) the ruler, the father (was) the raja", a reference to the government of the rajadom and to the encompassing polity of Sikka in which one is reminded that the rajas gained their powers from the tana pu'ang.

The histories of Sikka credit Bata Jawa, a descendant of the eighth generation after Lai Sao, and his son, Igor, with establishing the major customs governing religious practice, marriage and the settlement of disputes in Sikka. His son, Baga Nang, a descendant in the tenth generation after Lai Sao, was the first Sikkanese to settle at the site of Sikka Natar. The history recounts how Baga Nang acquired the site from its aboriginal inhabitants, the people of Hokor, by an act of subterfuge and usurpation, a theme common in the origin myths of eastern Indonesia, by which he caused the Hokor people to flee the site. Only one of the aboriginal Hokor people remained behind, and that was the tana pu'ang, the "source of the earth" who held authority in matters pertaining to the rituals of the land and agriculture. 
In the narratives of the Sikkanese history, Bata Jawa's and Igor's creation of hadat and Baga Nang's acquisition of the site of Sikka Natar are prelude to the main story, which is that of the foundation of the rajadom by Don Alésu in the eleventh generation after Lai Sao.

Alésu was the third raja of Sikka according to the royal genealogies, the first raja having been Mo'ang Igor, the son of Mo'ang Bata Jawa, and the second Mo'ang Baga Nang, the son of Mo'ang Igor. In the Kondi text and in the mythic histories which I recorded from informants in the late 1970s, Alésu is a culture hero of considerable stature. The Ata Sikka take considerable pride in their Catholicism and in the time they have been Catholics, which by their account has been almost four and a half centuries. More than any other element of Sikkanese life and dominion over their rajadom, Catholicism is at the root of Sikka's claim to legitimate rule in eastern Flores. Alésu is the figure who brought Catholicism to Sikka, who converted the people, and who thereby secured Sikkanese hegemony over the whole of east central Flores. Thus, the origin and foundation of the rajadom is linked inseparably to the coming of Catholicism to the Sikkanese.

In the narrative, the heads of the clans and domains of Sikka chose Alésu to replace Baga Nang after his death. After becoming raja, Alésu travelled to Malacca, where, under the patronage of Raja Worilla, he converted to Christianity and was educated in theology and law. After three years, Alésu asked Raja Worilla to allow him to return to Flores and to provide a teacher of religion for his people. The Raja sent his son, Augustinu da Gama, to Flores as a teacher. Alésu then returned to Flores with the great wealth which Worilla had given to him when he departed from Malacca. Upon reaching Flores, he resumed his position as ruler of the Sikkanese with the assistance of Augustinu da Gama. The wealth with which he returned he distributed among the mo'ang pulu, the "ten nobles" of Sikka, the clan headmen, tana pu'ang and minor rulers of Sikka, thereby cementing the alliances upon which the rajadom was founded.

In the era of the rajadom, Sikka Natar was a stratified society consisting of four classes: the ratu and his kin, noblemen, commoners and slaves. The royal house of Sikka is Lepo Geté, the "Great House", and the people who made up the Great House bore the Portuguese name da Silva. Their name in hadat is Lésupung. Lésu is an elision of Alésu, who is recognized as the founder of the house, ${ }^{3}$ and pung, a polysemous word meaning: (1) to possess, possession (Bahasa Indonesia: punya) and (2) grandchildren, descendants. It is a reflex of the word pu, which means, among other things, "ancestors" or "forebears". Pung is semantically linked to the word $p u^{\prime}$ ang, which means "source", "origin", "trunk (of a tree)". People who are "Lésupung" are thus "the descendants of Alésu" and the people whose protogenitor was Alésu. 
Next to the ratu in rank were people of the nobility, who made up the kuat wungung, "houses", into which Sikka Natar was divided. Each noble house occupied a wisung, "territory" or "ward", in the village. All of the people of the kuat wungung have both hadat names and Portuguese names. In addition to da Silva, the name carried by members of Lepo Geté, the nobility of Sikka carried such names as Fernandez, Pareira, da Cunha, da Gomez, da Lopez, and so on. It was from the nobility that the mo'ang pulu, the "Ten Lords" came. In the reign of the last raja, the mo'ang pulu made up an advisory council to the raja and each $m o$ 'ang ruled his ward in Sikka Natar and lands and villages attached to it outside of the village of Sikka. In the 1930s, the Dutch reorganized the government of the rajadom and appointed kapitan to serve as resident administrators in the various administrative divisions of the rajadom. These administrators were largely drawn from the mo'ang pulu, the nobility of Sikka Natar, and were known as the kapitan lima, the "five captains", although in later years there came to be seven.

Each of the kuat wungung of Sikka Natar is said to have originated outside of Sikka and to be made up of the descendants of immigrants who joined the ratu at different times. Kondi (n.d.:11) identifies thirty-six places of origin, including east Flores, Lio to the west, Solor, Adonara, the Kei islands, Bima, Bali, Savu, Ambon, Kisar, Wetar and Sumba.

In the compilation of origins, the rajadom, which defined Sikka as a society, consisted of no indigenous people since the aboriginal inhabitants who occupied the site of the village, the people of Hokor, were forced to flee. Thus, the ruling village of Sikka is represented both in oral and textual sources as consisting of peoples of diverse origins. Among these various groups, the house of the raja is temporally prior to all of the others and thus claims social and political precedence in the community.

\section{Authority, Precedence and Delegation in Tana 'Ai and Sikka}

In both Tana 'Ai and Sikka, the dynamics of social organization, whereby new social groups are created within society and alien groups are incorporated, produce a social order which is represented in terms of its origins. ${ }^{4}$ The tracing of contemporary social relations is structured just as the processes of generation are orderly and origins themselves are structured. By reference to their origin structures, the members of a community maintain the continuity of society as it changes. Indeed, it is upon change that origin structures are predicated. In all cases and at every level of social life, from the ideological to the immediately pragmatic, the origin structures of Tana 'Ai and Sikka allow for the transaction of authority. Thus origin structures can be mapped by tracing the authority structure in a community at a given time. 
In both societies, just as no group claims an autochthonous origin, no group or person claims innate authority to act. Rather, all authority is traced to a source and, except in the cases of the tana pu'an of a Tana 'Ai domain and the tana pu'ang of Sikka, a person acts or exercises power legitimately, i.e., in accord with hadat, only if the authority inherent in the act has been delegated by another person closer to the source in a chain of precedence.

Precedence systems are multiplexly asymmetric and open ended, which is to say that new groups can be generated and power delegated endlessly. It is only at the source that problems of a conceptual or logical nature arise. In Tana Wai Brama, for example, the tana pu'an holds his authority by virtue of his membership in a group whose members are descendants of the first of the ancestors to settle in the domain. Even so, the power and authority of those ancestors was not simply a consequence of their priority of immigration and primacy of precedence, but derives from an act of usurpation - of land, power over animals and ritual potency - of the aboriginal spirits of the domain (cf. Lewis 1988:270-274). Similarly, the authority of the ratu of Sikka derives from the usurpation of Sikka Natar's aboriginal inhabitants, whose descendants are, even today, recognized as the tana pu'ang. That authority is represented as having been delegated by the tana pu'ang, who retains ritual authority over the land and it is upon this delegated authority that the ratu's legitimacy is founded.

In both societies, authority and power are linked in such a way that authority is prior to power. So, too, the person who holds authority is prior to and holds precedence over the person empowered to act. Thus, in both Tana 'Ai and Sikka, there is a principle of delegation by which those who hold authority delegate to others the power to act.

Such delegation can be seen in the relation of the tana pu'ang of Sikka and the ratu. The Source of the Domain had ritual or religious authority over all the land of Sikka and its people. In the myths of the foundation of the domain, it is told that the Source of the Earth delegated to another person the power to act. That second person became the raja. Even in Sikka today, one finds a division of authority and power, the Source of the Domain, the hadat leader, exercising spiritual authority in the community which, over the years, has been delegated to the raja. In the process of this delegation, the Source's spiritual authority is transformed into secular, political power. This pattern, by the way, is so common in eastern Indonesia, that anthropologists use the term diarchy (rule of pairs) to describe the organization of sacred power and secular authority in all eastern Indonesian societies.

The Sikkanese rajadom was abolished in 1954 and by the 1960s the secular power of the raja was transferred to the local Bupati and the officials of his government. But to the people of Sikka, the basic division between authority 
and power has been maintained continuously in an unbroken sequence from the past.

Similarly, in Tana 'Ai, the Source of the Domain, the ritual leader of the community, delegates his authority to a hierarchy of ritual specialists who are thereby empowered to act, according to hadat on behalf of the Source. The Source himself, it is interesting to note, derives his authority in turn from his sisters.

To an English speaker, authority is (1) the power to influence or command thought, opinion or behaviour and (2) an individual cited or appealed to as an expert. Both of these definitions hold well enough for persons who have kuasa, newang and hak (Sara Sikka and Sara Tana 'Ai; note that kuasa and hak are cognates of words in Bahasa Indonesia), "power", "authority", "obligation", "right". People in both societies recognize authority both as influence to command thought, opinion or behaviour and as something characterizing an individual who is cited or appealed to as an expert of some sort. Such authority and authorities as persons command and influence only locally and on the basis of hadat. This means that authority is an aspect of hadat. And hadat is the "source" or "origin" of the community itself. One finds this relationship between origins and authority expressed in local mythic traditions, the myths handed down from the ancestors which serve as charters for the way things are and ought to be and which recount the creation, not only of the world, but of the social order. These are foundation myths which are cited as the authority for the way things are today. Thus things are the way they are today because that was the way they were in the past. 


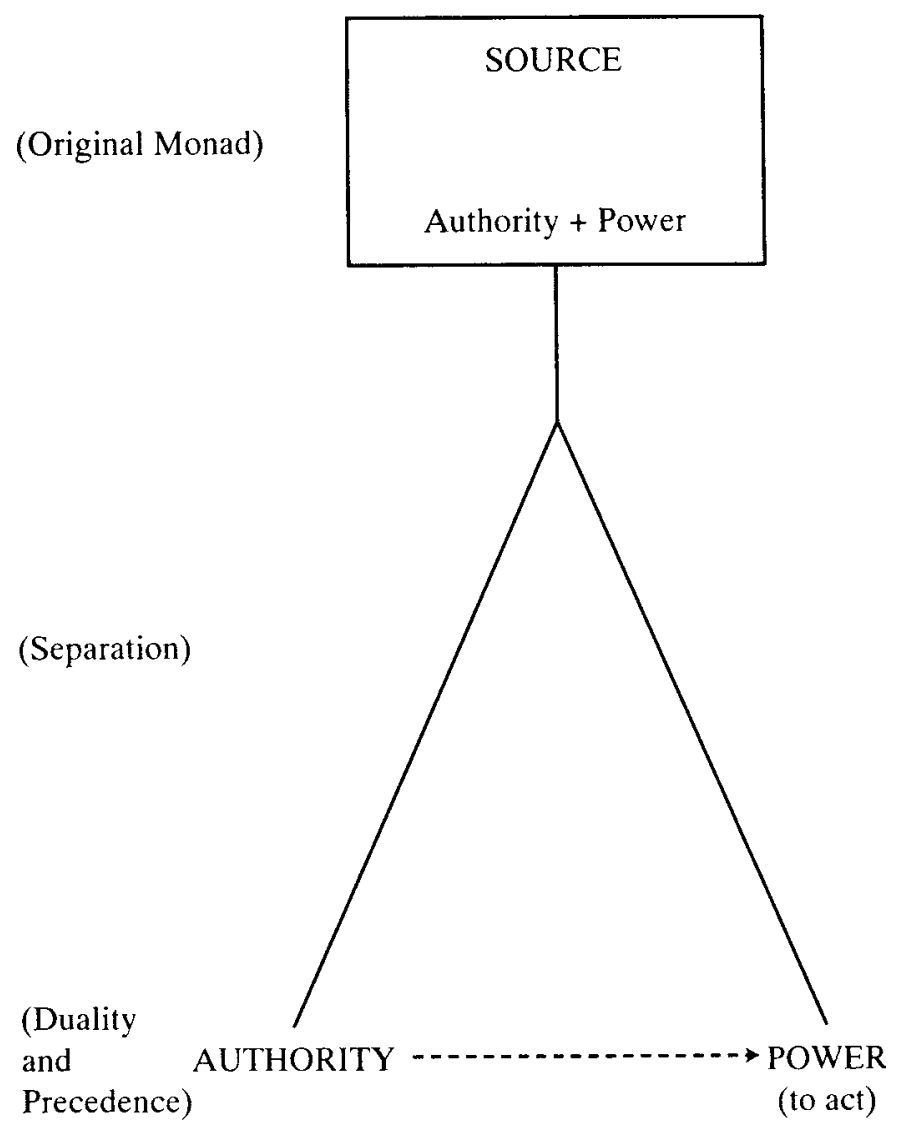

Figure 6

One of the practical corollaries of this division between authority and power and one of the practical results of the principle of delegation is that, in societies such as those of Timor and Flores, the person seen to do something, the person apparently empowered to perform an act, is not the person who has the authority to get the thing done. ${ }^{5}$

In the time of origins (or before the time of origins), authority and power are not separate but are monadically combined. In the creation of the social order, the two were separated, resulting in a dual division (Figure 6). In some societies, such as Sikka, the tana pu'ang, "Source of the Earth", once held all power. In Sikkanese myth, Don Alésu went to Malacca and there acquired agama (Christianity) which he carried back to Sikka. Agama (a foreign religion) enabled the establishment of the Sikkanese rajadom, but only after the delegation of power from the tana pu'ang to the ratu. Through this delegation and division of authority, the ratu acquired power and a diarchy was created. The tana pu'ang, who still held (and holds) authority, retired to the background: as source, he holds authority, but not power. The ratu, in turn, further delegated power to 
the mo'ang pulu, the "ten lords" or nobles of Sikkanese society who are themselves ranked in terms of their precedence with respect to the acquisition of power from the raja. Thus, with respect to Sikka, the general separation of authority and power must be rewritten to take into account the specificities of Sikkanese history and culture as in Figure 7.

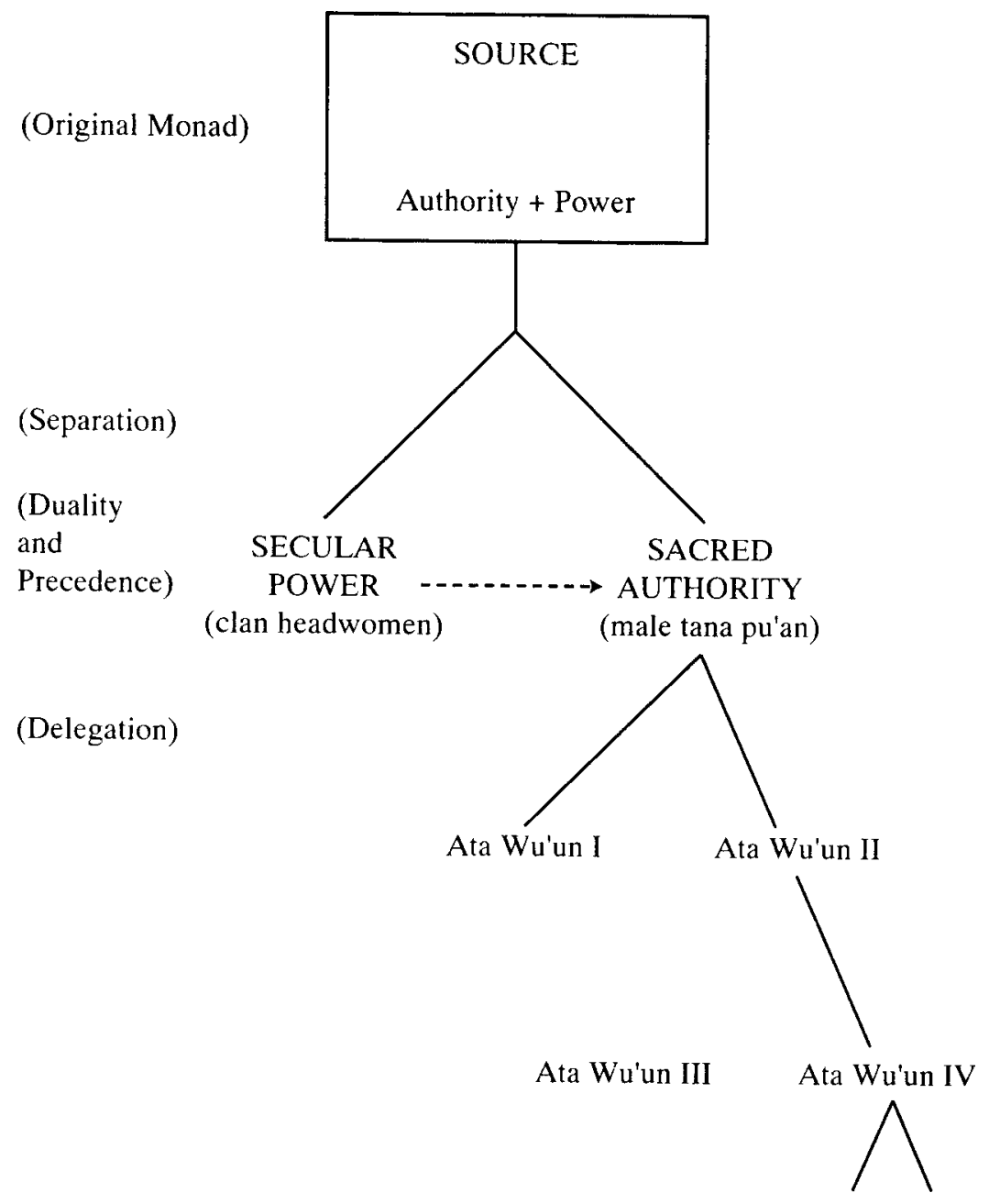

Figure 7

Two important points must be noted. First, the relations of the mo'ang pulu and the ratu appear hierarchical, as, with respect to power, they indeed are. However, this apparent hierarchy masks as essential heteroarchical diarchy between sacred authority and secular power, the relationship of which is as much complementary as hierarchical. Second, the principle which governs the apparent hierarchy is not one of gradations of an absolute power. Rather, in delegating power to the mo'ang, the ratu holds relative authority over them. 
The same relationship of authority to delegated power holds for the relationship of each pair of mo'ang as well. Thus at every level of the apparent hierarchy, what Fox (1989:52) has called recursive complementarity governs the structure of relationships. Thus, the relationship of the tana pu'ang to the ratu is one of authority to power; the relationship of the ratu to the highest ranking mo'ang is one of authority to power; and the relationship of each higher mo'ang to the next lower ranking $m o^{\prime}$ ang is one of authority to power.

In Tana 'Ai, the same basic principle works out in a different way. Tana 'Ai never had a raja and there is not the division of the sacred and the secular as we find in Sikka. The system is not, in other words, diarchical in the sense that the term describes the case of Sikka. Yet Tana 'Ai manifests a similar pattern. In the myths of origin of the Ata Tana 'Ai, the time before the creation of the social order was a time in which the major categories of later creation were monadically whole. But the idiom is one of life and death and male and female. In the precreation epoch, there was no death and there was no sex; human beings neither died nor were created through sexual congress and the firmament and the earth were connected. When the earth and sky were separated, male and female came into being as did the living and the dead. As humans came to be divided as male and female, so too did society come to be divided into clans, one of which, the founding clan, is temporally prior to the others. That is the clan of the tana pu'an, the "Source of the Domain". The Source of the Domain is the ultimate authority in social life and combines in his being both authority and power. However, as in Sikka, the creation of the social order required the delegation of authority as power. The Source of the Domain thus empowered the lesser clans which are themselves ranked according to the principle of precedence (Figure 8 ).

Once again, the tana pu'an delegates authority which becomes, through delegation, power and each ata $w u^{\prime} u n$ is related to every other ata $w u^{\prime} u n$ as either the delegator of prior authority or recipient of delegated power. The classificatory system at work is governed by complementary recursivity and not by absolute hierarchy. The pattern is set in the mythic histories of the domain, in which each clan received rights to land and the performance of ritual from the tana $p u^{\prime} a n$. The sequential order in which the tana $p u^{\prime}$ an delegated specific rights establishes the precedence of the clans. Today, those original relationships are refracted in the order of rights manifested in the performance of particular rituals. The power to perform is a function of those at the end of the chain of precedence; the earlier the precedence, the less active ritual practitioners are. 


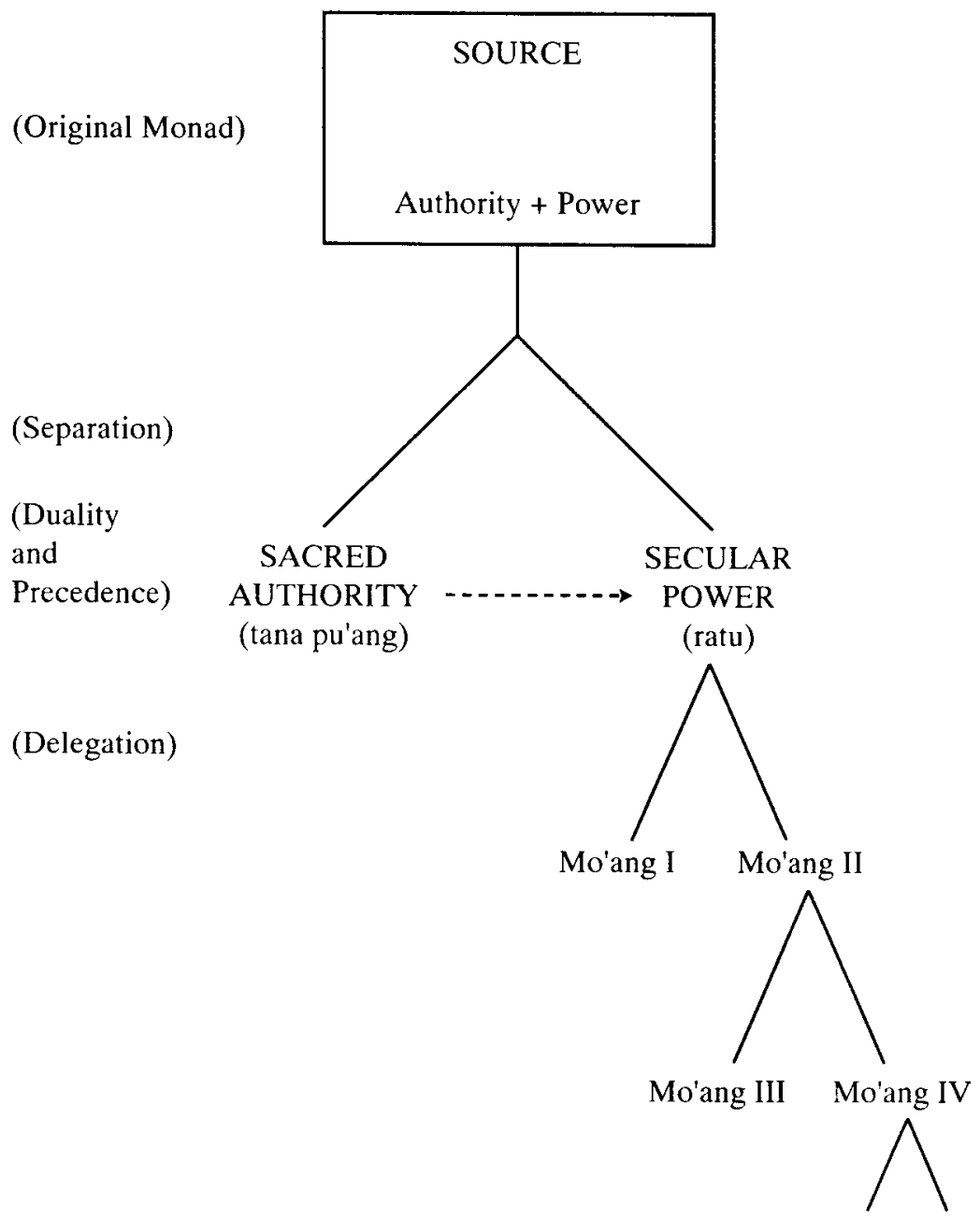

Figure 8

A single model can be extracted from the Sikkanese and Tana 'Ai cases (Figure 9).

\section{Conclusion}

Throughout eastern Indonesia, the people of local communities trace their origins from diverse sources. Typically, the people of a community may be divided into a number of what can be called origin groups, each of which claims a unique origin from another place (often another island). In some communities, such as Sikka Natar and the Domain of Wai Brama on the island of Flores, these groups are ordered in rankings that appear to be social hierarchies, but which actually reflect the sequence in time in which each group's ancestors arrived and joined the community. In Sikka Natar, major social groups called kuat wungung are so 
ranked with the first group claiming status as Source of the Earth, the group from which the ruling rajas of the old Sikkanese rajadom came claiming second position, and the remaining constituent groups of the village ranked in order of their ancestors' arrival in Sikka. In Tana 'Ai, the five sukun (clans) of the Domain of Wai Brama each trace an independent origin from ancestors who came from other regions of Flores and from other islands in eastern Indonesia. As in Sikka, the sukun are rank ordered in the ceremonial system of the community in terms of their temporal precedence. In addition, the lepo (houses) of which a clan is composed are also rank ordered in terms of the order in time in which they were created through affinal exchanges between two clans. On Flores, as elsewhere in eastern Indonesia, the precedence of origin groups is the principle underlying and generating what is manifested as hierarchy within a contemporary society.

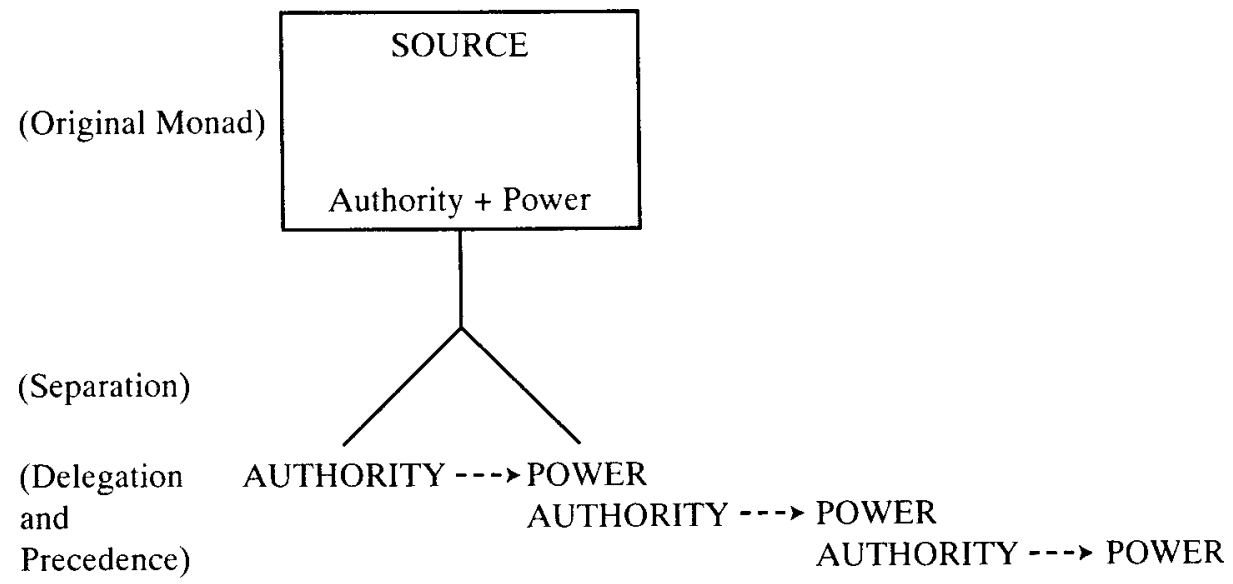

Figure 9 (cf. Fox 1989:52)

In the case of Flores, the royal house of Sikka Natar was linked over time by affinal alliance to other rajadoms on the island and on Sumbawa and Sulawesi. These links were essentially political and social, and not ceremonial, in nature. The ranking of the Sikkanese royal house in relation to others was established on the principle that wife-givers are superior to wife-takers and that the older an alliance, the greater its value. Thus, in contracting marriages with the ruling houses of other areas of Flores, the rajas of Sikka aimed to provide daughters in marriage to the sons of the rajas of Larantuka, Paga and Wolowaru while celebrating the antiquity of alliances in which they were wife-takers. Elsewhere on Flores (as in Tana 'Ai) analogous links between communities were (and still are) ceremonial in nature and not political. As ritual life reflects social precedence in these societies, it is likely that relations between such communities are also ordered in terms of precedence. ${ }^{6}$

Two points of theoretical import arising from the analysis of the social orders of Tana 'Ai and Sikka are worth reiteration. First, the order of relationships 
which obtain among the constituent groups of society are extremely fluid and dynamic and operate in such a fashion that relationships of statuses of persons within these communities are also flexible and change to a significant degree through time. Second, the dynamism of Tana 'Ai society is paralleled by a conception of history, authority and power by which the perquisites of status are easily transferable between groups, except that one group is, in terms of the mythic origins of society, immutably the "origin". In Tana 'Ai, that origin is represented by the Source of the Domain. Standing in a relation of priority to the Source of the Domain, however, is another veiled source which is represented variously as the women of the original clan (and the sisters of a Source of the Domain) and as the aboriginal spirits of the land. The same is true of the Rajadom of Sikka, in which the ratu was immutably the point of origin and reference for the reckoning of the social position of other groups in society. As in Tana 'Ai, prior to the ratu is a source of spiritual authority, the aboriginal Hokor people, who were usurped but whose spiritual authority over the land is recognized in the person of the tana pu'ang, the Source of the Earth. In both Sikka and Tana 'Ai, social order rests upon a conception of precedence by which power and authority are transacted among the constituent groups of society.

\section{References}

Echols, John M. and Hassan Shadily

1989 An Indonesian-English dictionary. Third edition. Ithaca: Cornell University Press.

Fox, James J.

1988 Origin, descent and precedence in the study of Austronesian societies. Public lecture in connection with De Wisselleerstoel Indonesische Studien given on 17th of March 1988, Rijksuniversiteit te Leiden, The Netherlands.

1989 Category and complement: binary ideologies and the organization of dualism in Eastern Indonesia. In David Maybury-Lewis and Uri Almagor (eds) The attraction of opposites: thought and society in the dualistic mode. Ann Arbor: University of Michigan Press.

Fox, James J. and E.D. Lewis

1993 'Ata Sikka of Flores, Eastern Indonesia. In P. Hocking (ed.) The encyclopedia of world cultures, vol. V: East and South East Asia, pp.19-22. Boston: G.K. Hall \& Co.

Lewis, E.D.

1988 People of the source. The social and ceremonial order of Tana Wai Brama on Flores. Verhandelingen van het Koninklijk Instituut voor Taal-, Landen Volkenkunde 135. Dordrecht, Holland: Foris. 


\section{Notes}

${ }^{1}$ For a brief description of Sikkanese society and culture see Fox and Lewis (1993) and Lewis (1988:9-19). The word negeri in Bahasa Indonesia means "land" and "country" and, in eastern Indonesia, "village" (Echols and Shadily 1989:387). Sikkanese writers before the 1950s and 1960s used literary Malay in which the word means "land" and "country". From the contexts in which the word is used in Kondi's history, negeri should be translated as "country" rather than as "village". It is thus the Malay equivalent of the Sara Sikka word tana, "land", "territory", "domain" and bears the connotation of "polity" of that word.

2 Kondi's history has not been published. It is an untitled work of some 76,430 words in typescript. In 1961, Kondi gave his history to Professor Clark E. Cunningham, who made a photocopy of the manuscript in Surabaya. The manuscript was then typed at the University of Illinois. In 1977, as I was preparing for my first fieldwork in Sikka, Professor Cunningham supplied me with a photocopy of the typescript. The manuscript has since been lost.

3 It is worth noting that in Sara Sikka, lésu is also the word for a species of eagle.

4 Thus the puzzle of why, in Tana 'Ai and Sikka, origin myths are essentially the narratives of a single group (clan Ipir and Lepo Geté, respectively) rather than of all groups can be understood: myths of origin are not histories for the sake of history; they are not intended to chart the unique histories of the various groups which make up society, but the way in which those groups came to form society. That formation is in both cases the result of actions by the central founding group alone. Hence, the mythic histories of Tana Wai Brama are the history of clan Ipir and, despite the multifarious origins of its people, the history of Sikka is the history of the royal house. The histories of individual groups may be (they are usually not) remembered, but they are not pertinent to the origin structure of society.

5 For an anthropologist, it does no good to ask the young boy who is killing a pig in ritual why he is killing the pig; one must locate and seek out the person in authority from whom his power to kill the pig has been delegated. The problem is that sometimes that other person is bound by hadat to remain mute when faced with outsiders. Here the problem is that, being the authority, such a central person does not take orders or suggestions from others but is rather the source of orders and suggestions.

6 It is possible that precedence may order not only relations of groups within societies and relations between petty states, but also the larger relationships of other communities and societies of the region. 